\title{
Historical Causes of Farmer-Herder Conflict in Kitui East Sub County, Kenya, 1895-1963
}

\author{
Winnifred Mwikali*, Diperuswafula \\ PhD student at the School of Arts \& Social Sciences - Moi University, Kenya
}

*Corresponding Author: Winnifred Mwikali, PhD student at the School of Arts \& Social Sciences - Moi University, Kenya.

\begin{abstract}
Farmer-herder Conflicts have been noted to be a chronic problem in Kenya. One of the most affected area being Kitui East Sub County. In this region, these conflicts Moi University, P.O. Box 3900, Eldoret-30100

involved two claimant groups fighting over access to limited natural resources like pasture and water. The two groups are the Akamba farmers and the Somali and/or Orma herders. These conflicts date back to pre colonial period although they intensified during and after the colonial era. The conflicts have led to socio-economic decline in the region. As such, determining the root causes of the conflicts is requisite to pursuing the much needed peaceful co-existence. The objective of the study was to trace the historical causes of farmer-herder conflicts in Kitui East Sub County, 1963-2013. Structural scarcity theory guided the study. 180 respondents were selected using Simple random sampling technique. Key informants were selected using Purposive sampling procedure. The study utilised four main sources of data collection namely; archival, interviews, FGDs and library search. The data was analyzed using descriptive statistics. The results were presented in narration form. The study established that the main cause of conflicts in Kitui East Sub County was competition over water and pasture. It is expected that the outcomes of this study will act as reference in the historiography on conflicts.
\end{abstract}

Keywords: Conflict; Farmer-Herder; Historical causes; Kitui East Sub County; Structural Scarcity.

List of Abbreviations: CICERO - Center for International Climate and Environmental Research, FGD Focused Group Discussion, KADU - Kenya African Democratic Union, KANU - Kenya African National Union, L.N.C - Local Native Council, N.S.C - National Steering Committee, SALW - Small Arms and Light Weapon

\section{INTRODUCTION}

The Farmer-herder conflicts in the horn of Africa region are on the rise. [1] support this view by observing that statistical comparison of Africa and other regions suggest that Africa surpasses in terms of civil wars and collateral destruction of infrastructures for economic development. Other scholars have also pointed out that the scarcity of natural resources has made the farmer-herder conflict to increase both in terms of recurrence and intensity in semi- arid Africa. For instance, [2] argues that as individuals and groups in a society compete to maximize their share of the limited resources, the struggle leads to conflict while [3] are of the view that most of the conflicts arise when customary practices are no longer viewed as legitimate or consistent with national policies, or when entities external to a community are able to pursue their interests, while ignoring the needs and requirements of the ,insiders ${ }^{\text {ee }}$. Conflicts, therefore, emerge from inequalities in accessing or controlling resources. In a similar study, [4] points out that in the absence of strong local institutions, when pastoral groups struggle to maximize their share of the limited grazing resources, especially during droughts, competition and conflict may arise. By triggering scarcity and deprivation, drought therefore may not only cause conflict but also compromise livelihoods. Similarly, according to [5], resource scarcity can have the potential to drive society into a self-reinforcing spiral of violence, institutional dysfunction, and social fragmentation.

In Kenya, resource based conflicts specifically water and pasture in arid and semi-Arid areas have been a major cause of conflicts. This revolves around livestock and the need for water and pasture. It is further worsened by the harsh climatic conditions. This water shortage coupled with shortage of pasture sparks competition which leads to conflicts between rival groups. In a supporting view, [6] has reported 
that the drought of the year 2011 in the arid northern Kenya depleted pasture and dried water points in Moyale, triggering inter-clan attacks and counter-attacks where seven people were killed in Burji, Moyale town. In addition, he cites other examples of conflicts which include the Samburu and Rendille conflicts over water and grazing land and the Pokomo and Orma pastoralistse conflicts over grazing land and water.

In Kitui East Sub County which is the focus of the study, farmer- herder conflict date back from the pre-colonial era when the Somali and Orma communities used to raid the Kamba for Cattle. However during the colonial period, with the overcrowding of Africans in the reserves which were created for them by the colonial government, the conflict intensified. This was due to the limited land for pasture and water sources. In another policy by the colonial government to control soil erosion in Ukambani, the Endau catchment area which had been a source of livelihood for both the farmers and the herders in the study region were protected from public access by the colonial government. This was done in 1948 when the colonial government decided that the Endau forest should be protected. The colonial government then evicted all people from the forest [7]. These policies had a very negative effect on the interactions between the farmers and the herders in Kitui East Sub County as they excluded both of them from important sources of water, forest products and drought grazing areas and limited the area available for cultivation. They also restricted livestock movement. This evictions therefore played a key role in creating conflicts which has been experienced repeatedly in Kitui East Sub County that further impede flexible interactions and socio-economic development in the study area. The colonial laws also excluded pastoral populations from the dairy and livestock markets. As a result, populations were disenfranchised and impoverished. This study established that this land tenure systems created during colonialism are still present today and have become the historical basis for the conflicts witnessed in the study area.

\subsection{Theoretical Framework}

The study was guided by the structural scarcity theory.

\subsubsection{Structural Scarcity Theory}

This theory emanates from environmental scarcity theory advanced by [8]. Scarcity is the limited availability of a commodity while structure means institutions. So structural scarcity sets in when social, economic or political structures or institutions systematically deny people or communities the ability to advance their socio-economic development hence unable meet their basic needs. These institutions may include political institutions like the government, political affiliations or social institutions like ethnicity, clannism, racism, religion, gender among others. [9]. Structural scarcity may therefore entail unequal accesses to resources, to political power, to education, to health care, or to legal standing. In the same vein, [10] has argued that when vital resources such as fertile land become scarce due to population growth and unequal access, impoverished people often move into ecologically-sensitive areas such as hillsides, tropical rain forest, and the areas at the risk of desertification. The rising population in these areas combined with unsustainable land use practices, leads to environmental degradation and further scarcity. This in turn leads to conflict over the limited resources.

The argument is clearly seen in the case of Kitui East Sub County where the study established that the farmers and herders used to derive their livelihood from Endau Hills during the drier seasons. The hill became the major cultivating and grazing area. However, in 1948, the Endau hill was protected from public access by the colonial government. The colonial government went further to evict all the occupants from the hill. These policies had a particularly negative effect on interactions between the farmers and the herders in Kitui East Sub County as they excluded farmers and herders in Kitui East Sub County from important sources of water, forest products and drought grazing areas and limited the area available for cultivation. In the long run, the eviction led to ecological marginalization [11]. [8], Avers that unequal access to natural resources in a given society makes them scarce for large segments of populations. This is true in the study area and Kenya in general. It was first witnessed during colonial period when the colonial government provided the white settlers with the most fertile land duped the "White Highlands" while the blacks lived in the reserves with infertile soils. Resources were also unfairly distributed. For instance, the Africans were pushed into the reserves with infertile soils while the white settlers controlled access to rich and fertile agricultural and grazing land. Kitui East Sub County was one of the African reserves. [12] Study on dry lands exemplifies this theory as it points out that the dry lands have been seen as having low economic potential and being politically unimportant, 
as a result, government allocations for development in the dry lands have often been low. In Kitui East Sub County for example, there has been very little investment in piped water provision, despite there being several permanent water sources on the hill within only a few kilometers distance from most villages. There are currently three functional or partly functional water pipelines, supplying villages to the west and south of the Endau hill. Several other water projects failed due to corruption among the organizations carrying out the project, poor quality of pipes and poor engineering, as well as lack of maintenance. Notably, the drier areas to the east and north of the Endau hill, including Malalani, have been unable to complete water projects that were started. This has led to the two user groups (Somali and/or Orma herders and Akamba farmers) fighting over the limited resources which in turn has led to loss of livelihoods, reduced access to education and also health care.

\section{Material AND Methods}

The study adopted the descriptive survey design which is appropriate because it does not manipulate variables or arrange for events to happen. Simple random sampling technique was used to select a sample of 180 respondents. Purposive sampling procedure was then used to select key informants. Interviews were held with key respondents to gather expert opinion about conflicts from people with special knowledge. The experts formed the key respondents in the study. In addition to the interviews, focus group discussions (FGDs) were held. They were held with Community members, Members of Area Peace Development committees and Local Community Leaders. Qualitative approach was used for data analysis. The data was reported in narrative form.

\section{STUDY FINDINGS}

The study findings were presented in narrative form.

\subsection{Causes of Farmer-Herder Conflicts}

The objective of the study was to trace the historical causes of the farmer-herder conflict in Kitui East Sub County. The results are discussed below.

\subsection{Competition over Watering Points}

'Why blame nature?' is a question often asked in serious analyses of agrarian crises. The object of the question being to underline the complexity of agrarian crises rather than to discount the role nature may play in generating such crises. In a nutshell, the argument is that what appears as nature-induced crises are usually socially-induced crises [13]. This means that the fact that a region is dry, it is not a warrant for it to suffer economic and ecological marginalization. The problem of water scarcity in dry areas is one that can be solved by looking for alternative sources of water and advising the farmers to irrigate their crops. However, the past governments have never bothered to address the of water issue in Kitui East Sub County. All the past regimes have favored the areas with reliable rainfall, hence marginalizing the geographically disadvantaged areas. To begin with, the policy of pacification for the hinterlands by the colonial government meant that it only focused their development efforts mainly on the more fertile areas foremost occupied by white settlers. This led to ecological marginalization of the dry areas like Kitui East Sub County. [14]

This practice of favoring the central regions was continued after Kenya became independent in 1963 , with the expectation that development would trickle down to other areas. However this never happened. Looking at the water scarcity in Kitui East Sub County, it's clear that the Sub County has been neglected by the government. There has been very little investment in piped water provision, despite there being several permanent water sources on the hill within only a few kilometers distance from most villages. There are currently three functional or partly functional water pipelines, supplying villages to the west and south of the Endau hill. Several other water projects failed due to corruption among the organizations carrying out the project, poor quality of pipes and poor engineering, as well as lack of maintenance. This has led to the two user groups (Somali and/or Orma herders and Akamba farmers) fighting over water and pasture. This is also supported by [15] who observe that the dry lands have been seen as having low economic potential and being politically unimportant, as a result, government locations for development in the dry lands have often been low.

Focused group discussions revealed that water supply and its availability in Kitui East Sub County depends on the seasons, with big variations between wet and dry seasons. Severe shortages are usually reported during the dry seasons, which is a common occurrence in the area. According to the leaders of 
the well owners ${ }^{\text {ee }}$ association, the Akamba people rent the Somali people wells during the dry season. The Somali and Oromo herders pay Akamba well owners for each well they use to water their livestock. A whole herd for a period of one month is charged between Kenya Shillings (Kshs) 10,000 to 20,000 whereas for each cattle, donkey and camel it ranges between Kshs 50 to 80, goats and sheep are charged Kshs 20 to 40 for each animal.

Table3.2: Payment for Watering the Herds and Flock in the Shallow Wells

\begin{tabular}{|l|l|}
\hline \multicolumn{1}{|c|}{ Watering payment of livestock herds and flock } & \multicolumn{1}{|c|}{ Kenya shillings } \\
\hline Pay per herd/ period (1 month) & $10,000-20,000$ \\
\hline Pay per head per day of livestock (cattle, donkey and camels) & $50-80$ \\
\hline Small stocks (per stock) per day & $20-40$ \\
\hline
\end{tabular}

Source: [16]

The Somali and Oromo claim that the Akamba well owners con them in selling water, they rent them wells that they have sunk but within a short duration, they chase them away, although the Somali and Oromo have paid for it. According to the Akamba well owners, conflicts arise as they bar the Somali and Oromo from accessing water in the wells at Engamba River which they have not paid for. This is because these wells are on their land and were sunk by the Akamba men for their domestic use. The Akamba claim that even though the Somali and Oromo hire out or pay for the water initially, they finally force themselves to all the wells even those they have not paid for. This creates a scenario which calls for struggle for ownership and domination. This is what leads to the spread of the conflict as more and more Akamba men struggle to protect their water sources and the Somali and Oromo struggle to occupy and own them. According to [16], the control and organization of shallow wells is inherited within a lineage and is the responsibility of the well council to oversee its use. It was reported that the purported well owners who are Akamba community elders carefully consider the allocation of watering rights for the Somali and Oromo who are considered as outsiders by the Akamba farmers. The decisions which are taken by the well owner or Akamba community elders sometimes include exclusion of outsiders. The allocation of water and grazing sites to outsiders for use in the Akamba homeland is negotiated by the council of elders (atumiamathome) who determine resource use patterns.

The study also established that the Akamba people depend on deeply dug wells for domestic use and irrigation while the Somali and Oromo herders are then left with no choice but to turn into the same wells belonging to Akamba to water their animals. The Somali and Oromo herders have to rent these wells from the Akamba farmers but sometimes they invade the wells without renting them. This leads to conflicts in the study area. There have also been disagreements when Somali and Oromo cattle and/or camels have been watered in other water wells than those rented for. This has in most cases led to violent conflicts that have gone on for a long time. The above revelations justify the structural scarcity theory as it can be argued that the lack of water for the local communities has not been addressed by the government structures hence, structural scarcity of water leading to the farmer-herder conflict in the region.

\subsection{Competition over Pasture}

Before the era of colonialism, the Africans tenure system depended on expanses of open, communally held pastureland which both the farmers and the herders shared with minimal conflicts. In the colonial period, there was an extensive land seizure and enclosure programs.

With the advent of colonialism, the colonial government came up with the infamous colonial land policies which aimed at creating white highland for the white settlers. This mode of colonial economy necessitated deliberate land alienation from African communities through colonial land policies. This is according to [17]. Some of the colonial land policies included the Land Regulation Act of 1897 which gave settlers certificates of occupancy for 99 years, The East African Land Order in Council of 1901 defined crown land as all public land that is not private. Private land included land occupied by the Europeans and Africans. The Crown Land Ordinance of 1902 said that all empty land could be sold at two rupees per acre or rented out at fifteen rupee per 100 acres per to Europeans. In 1904, the first African reserve was created for the Maasai. Consequently, by 1920, land not owned by Europeans eventually became crown land. Africans owned no land according to the European law [18]. Subsequently, by 1920, the Akamba, just like the other Kenyan communities, had lost effective access to about two-thirds of the land they had formerly controlled including their most fertile lands and half of all their pasture land. Along with some of their best grazing land, they lost the freedom to migrate seasonally and periodically in search of water, pasture, and cropland [19]. Although the study region 
was not part of the white highlands, the people who were evicted from the white highlands moved to this area leading to overpopulation. For the communities in Kitui East Sub County, the crisis of the era was one of land alienation, as settlers disrupted their tenure system and took away their land. At the same time, the state barred the herders from movement which deprived them the freedom to seek for pasture for their animals.

Following the above land laws, the Africans were therefore moved to the reserves. The results of that were over population and overcrowding of the Africans in the reserves. Due to the limited land in the African reserves, there was also overgrazing which led to serious soil erosion. [19] further avers that, the colonial officials blamed the Akamba backward cattle rearing methods and their primitive crop production methods for the problem. Colonial officials and observers, while recognizing the epidemics, blamed Akamba cattle-rearing practices as well as their "primitive" standard of living for the magnitude of the disaster. To counter the soil erosion problem, the colonial government came up with soil erosion control measures. Here, colonial policies focused on soil erosion control, terracing, protection of riverbanks and other environmental protection measures. Consequently, the colonial government introduced destocking policy in the whole Ukambani region. [20], describes Akamba protests in 1937 which was against the government's use of force by the government to destock and confiscate livestock. This is a clear indication that the colonial government never bothered about the welfare of the people.

In 1948, the colonial government decided that the Endau forest should be protected and evicted all people from the forest in the same year. While the local population and chiefs were unhappy about the eviction, they had little power to protest or voice their concerns against the colonial District Commissioner. The colonial administrators used their own power and discretion to declare forest reserve [7]. This report further gives an account of a visit by the divisional forest officer and the Forester Machakos and their tour of the entire Kitui district in September, 1948. After this tour, the two officers decided to ask the L.N.C to declare certain hills and ranges as reserves by March 1949. Following the above orders, the Endau hill, the main catchment area in Kitui East Sub County, was gazetted. It was to be owned by the government, and managed by the Forest Department. [11], attest to that by emphasizing that the Endau Hilltop Forest is a gazette forest managed by the government as a catchment area and ecologically sensitive ecosystem. These policies had a particularly negative effect on interactions between the farmers and the herders in Kitui East Sub County as they excluded farmers and herders in the region from important sources of water, forest products and drought grazing areas and limited the area available for cultivation. This played a key role in creating conflict that has been experienced repeatedly in Kitui East Sub County and which further impede flexible interactions and socio-economic development in the study area.

Another colonial development was the swynnerton Plan. In 1954, the colonial government implemented the Swynnerton Plan, a land reform program that continues to shape the evolving landscape in Ukambani and the rest of Kenya even up to date. The Swynnerton Plan was made to bring reforms in land tenure, consolidate fragmented holdings and issue title to individuals to encourage the intensification and development of African commercial agriculture [21]. The above policies thus, excluded pastoralists from many of their traditional grazing areas and restricted livestock movement by encouraging private land ownership. The colonial laws also excluded pastoral populations from the dairy and livestock markets. As a result, populations were disenfranchised and impoverished. This study established that some of the land tenure systems created during colonialism are still present today. Further analysis from the focus group discussion showed that resource scarcity is exacerbated by recurrent droughts and overgrazing of palatable and more nutritious grasses. In addition, weak and inappropriate formal institutions in the study area coupled with the inability of traditional institutions to manage conflicts and secure property rights contribute to the intensification of violent conflicts and animosity among resource users in the area.

Result indicated that there is a kind of competition between Akamba farmers and Somali and Oromo herders for grazing pasture. Disputes about the use of the residual plains of Engamba River that traverse the area is a source of farmer-herder conflicts. The residual plains are used for (dry season) farming of vegetables. Farmers complain that during the dry season, herders normally allow cattle to wander along the entire plain pretending to be in search of water and pasture, but the real aim is to prevent the farmers from farming in the plains so as to have exclusive use of them. The farmers also claimed that when Somali and Oromo lease pasture from Akamba farmers, the Somali and Oromo herders graze unrestricted, no matter what area they lease. They even feed their cattle with the grass thatched houses. 
Akamba also claim that Somali and Oromo have money; they bribe local administration so that even when there are grievances between the two communities, the administration takes side with the herders.

\subsection{Incitement by Political Leaders}

Before the imposition of colonial rule, Kenya had no trans-ethnic political structures. But with independence in 1963, that changed with irrevocable consequences. To get to parliament, a candidate had to win an election in his home area. To galvanise support meant playing the ethnic card. Playing the ethnic card was also useful because wealthy politicians were able to make a vote in their favour more worthwhile. As [22] reminds us, "the importance of wealth as a route to power, and of political power as a route to acquire both wealth and access to state resources has also meant that the same elites dominate both politics and economics and fight their battles in both spheres." After Kenya's independence in 1963, local and presidential elections have been much influenced by ethnic politics. Helped by the great personal powers of the President, the candidate to be elected was expected to use these powers to help his own ethnic group. In his shadow, the surrounding elites benefited as well and did much in their power to strengthen their positions, little concerned with any legal restrictions. Political elites even had their private militias, which were occupied with intimidation and repression during election periods [23]. During the regime of Daniel ArapMoi, political freedom was at alltime low in post-independence Kenya, by then a de facto one-party state. Moi defended his one-party system by warning for chaos as the result of multi-party elections. The reintroduction of multi-party elections in 1992 was, indeed, marked by violence. [24].

Similarly, in the study area, local politicians and political parties represent another structure that influences conflict in the study area. Many local politicians have taken advantage of the expectations of the local population that they will evict the herders from the region if they win. These politicians have sought to rally support by inciting conflicts. As a result, the political agenda has been diverted away from issues of landlessness, inequitable distribution of land and resources, and development of water supply and other basic infrastructure.

The interviews reviewed that during the 1970s, raids by the herders were politically instigated by powerful people and also facilitated by those in authorities with ethnic preferences. They relayed accounts of raided cattle being driven into army trucks and sold in distant markets. On the other hand, there were also speculations of powerful Akamba leaders who also ordered for the massacre of the herders.

[12] Describe how, in 2006, strong internal wrangling took place among Akamba politicians, elders, traders and local administrators over trade with herders of Somali and Orma ethnic origin. Trade with other Akamba pastoralists was not questioned. Some politicians and local leaders caused tension and created an atmosphere of conflict among the Akamba farmers and Somali and the Orma communities. Some leaders organized public meetings where it was decided that trade with people of Somali and Orma ethnic origin was to be discontinued. When some local Akamba continued to trade with the herders, those in favour of excluding Somali and Orma rallied youths to attack the herders' camels, local government administrators who favored that trade were suspended. Some politicians in particular influenced the office of provincial administration not to allow the herders to interact with the Akamba peacefully.

Some respondents observed that at times, politicians incited their own communities to attack targeted members of other communities, thus brewing farmer-herder conflicts in the area. This is because the farmer-herder conflicts are synonymous with socio-economic inequality from which politicians and elites consistently vow to liberate their individual communities. This dream is achieved by outwitting the others who compete for similar socio-economic resources. Some politicians promised that if elected, they would make sure that no Orma or Somali and Orma herder would be allowed to access water or grazing pasture. [25] corroborate most of these observations in their research in Mandera East Sub-County which found that mostly, the pastoral conflicts in the region are as a result of political incitement. [26] is also in support of this as he concludes that often, incitement mutates into violence, which in turn becomes selfperpetuating, geared by revenge attacks on the perceived ethnic community enemies.

\subsection{Marginalization in Access to Infrastructure and Natural Resources}

Kenyan dry lands have historically been disadvantaged in the distribution of public resources for development and in services provision [12]. The availability of livelihood options that are well adapted to drought has been reduced due to the failure of the state to provide security. In the arid and semi-arid 
areas such as Kitui East Sub County, the nexus between development and security is evident. The lack of socio-economic opportunities is a contributing factor to the region's insecurity, which consequently contributes to the region's lack of economic opportunities. Thus, it becomes a vicious circle of poverty and insecurity.

[7], Shows that the dry lands have been seen as having low economic potential and being politically unimportant. As a result, government allocations for development in the dry lands have often been low. Looking at the water scarcity in Kitui East Sub County, this argument can be justified. There is no piped water provision, yet, there are several permanent water sources on the hill. within only a few kilometers distance from most villages. There are currently three functional or partly functional water pipelines, supplying villages to the west and south of the Endau hill. This has led to the two user groups (Somali and/or Orma herders and Akamba farmers) fighting over the limited resources which in turn has led to loss of livelihoods, reduced access to education and health care and also dependency.

Marginalization in access to basic infrastructure and natural resources was cited by all the respondents as a cause of farmer-herder conflicts in Kitui East Sub County. Several stakeholders blamed the government for not providing enough security, in that the security personnel in the study region are very few, road network is not developed; the courts are placed far apart and the nearest court is in Kitui town which is 85 Kilometers away. Schools and health facilities are few and the majority of the youth are unemployed. The inadequate financial and material resources have rendered state security agents and the communities' peace organs overwhelmed by the unending incidents of farmer-herder conflicts in the Sub County.

A research by [27] corroborates these findings as it shows that the widening economic disparities based on regional or ethnic divisions have the effect of exacerbating tensions between communities thus creating potentially explosive situations which can result in the outbreak of violence.

\subsection{Ethnic Animosity}

The period of colonial rule saw the colonial government using the divide and rule tactic which entailed an indirect rule system in which the colonial chiefs enjoyed support from the colonial government such as protection against their enemies and consequently were used as instruments/ puppets of the government. For instance the Maasai community which was used by the colonial government to suppress other communities.

During the armed struggle for independence, the British employed the strategy of divide and rule. to discourage the insurgency and inter-tribal groupings; each community was to hole up in defined districts. The seeds of tribal suspicion were gradually being sown in the name of containing the Mau Mau uprising in 1948. The 1949 Beecher Committee on Education was very influential in advancing ethnicity, as it advised that pupils from class one to four be taught in vernacular, further knotting the ethnic fiber and incorporating tribal identity from an early age [28].

[29], Show that in the eve of independence, ethnic interest continued to shape the grievances of the independent leaders. This was especially evident during the 1962/63 Lancaster conference in London where ethnicity took centre stage and strongly determined the demands of the Kenyan participants. There was fear that the 'big tribes' would dominate the 'small tribes'. As such, there was a sharp division between KADU and KANU, apparently representing ethnic demands of their respective tribes.

Ethnic animosity was cited by some of the respondents as a prime factor in igniting farmer-herder conflicts in Kitui East Sub County. This scenario is provoked by inter-ethnic mistrust and hatred which sustain stereotype remarks that legitimize violence by some communities against others. Ethnic nationalism quickly translates into undesired ethnocentrism where the warring parties are broadly defined and mobilized in terms of their ethnic groups.

This trend of behavior fits in the views of Structural Scarcity Theory. The existing situation in Kitui East Sub County is prompted by disparities in access to natural resources, which result to ethnic agitations in order to mobilize for resources and articulate their interests. Concerning ethnic animosity, [16] is of the view that the dawn of multi-party politics in Kenya brought in its wake new dimensions of conflict whereby communities were divided along political and ideological lines, which gave rise to protracted and institutionalized waves of ethnic animosity. 


\subsection{Presence of Illegal Small Arms and Light Weapons}

[30], Assert that one of the main legacies of European colonialism was the introduction of sophisticated weaponry in Africa resulting in more aggression among certain ethnic groups. They go further to say that colonialism precipitated the collapse of ancient principles of balanced reciprocity in the practice of warfare between ethnic groups, and thereby warfare changed from being a means to adapt to new circumstances to an agent of the outright destruction of other groups. Before the imposition of colonial rule, in underdeveloped regions such as the Kitui East Sub County, conflicts were fought with spears, machetes and bows and arrows. This made them less deadly. However, the introduction of small arms and light weapons (SALWs) has made conflicts much deadlier. [26]

The structural scarcity theory was qualified since one hires a gun because the government has deprived him of self-security which it is supposed to provide. Security is one of the rights of the Kenyan citizens, failure by the government which is the structure responsible for providing security to its citizens breeds scarcity of security, hence structural scarcity.

\subsection{Cattle Rustling and Banditry}

The perspective of [13] is that the introduction of the capitalist mode of production by the British imperialist did not eliminate pre-capitalist modes but rather reshaped them. Thus, indigenous modes of production were progressively subordinated to the capitalist mode through a process of dissolution, conservation and transformation. In colonial Kenya, for example, land alienation, taxation, and forced labor were some of the mechanisms used by the colonial state to erode or dissolve the selfsufficiency of African economies. Thus the Africans raided even more in order to accumulate more. As noted by [31], in pre colonial period, cattle rustling was regarded as a means of expanding grazing land, replenish lost herds following harsh climatic conditions and to obtain bride wealth. However with the articulation of African modes of production to colonial capitalism, the motive of raiding changed. The herders for instance started raiding for commercial purposes.

\subsection{Loss of Power by the African Traditional Authorities}

[32], observes that another factor which affected the relationship between the farmers and the herders in the region by the colonial government was the introduction of indirect rule which necessitated the creation of the position of the colonial chiefs. Before the imposition of colonial rule, Kenya had no trans-ethnic leaders and also had few ethnic political structures. Authority was personal and local, a function of age, lineage, supernatural abilities, and wealth and leadership skills, supported by the communal wisdom of elders and the physical power of young men. All societies were gerontocratic and relatively egalitarian, and all relations were personalized. [22]

[33], points out that the colonial system created institutional gaps by weakening the African Traditional authorities. He further observes that the absence (or incompetence) of authorities ${ }^{\text {ec }}$ hierarchies to enforce rules, asks for new or improved institutions to bridge those gaps. These institutions are based on customary law. Traditional authorities have their roots in tradition and culture for their legitimacy, whereas in modern societies, legitimacy of authorities relies on a legal (written) framework, with leadership often based on democratic principles [34]. This loss of authority of elders has also affected the nature of conflicts. The authority of elders to settle conflicts is limited in the modern times especially where conflicts which are larger than the network of the elders, conflicts which arise about new resources over which elders traditionally do not have legitimacy (e.g. boreholes or formalized land tenure), or when actors are not depending on economic resources managed by elders [35]. According to the above views, it is clear that the traditional elders lost authority to colonial chiefs hence they are unable to prevent the conflicts.

In an interview with an assistant chief it was revealed that cattle rustling and banditry feature prominently as causes of farmer-herder conflicts in Kitui East Sub County. The raiding by the Somali and/or Oromo force the Akamba youth to react violently in order to protect their families and their livestock. The Somali and/or Oromo"s also retaliate violently leading to violence. The police try to disarm the Somali and/or Oromo who put up a lot of resistance. Cattle rustling and banditry is at this level motivated by economic interests. This is in line with a report by [36] who noted that raiding and cattle rustling have contributed to violent conflicts within and between pastoral communities. He argues that raiding and cattle rustling have a long history and have become an aspect of traditional pastoralist culture. He further observes that Cattle rustling has intensified and are now beyond the traditional rustling. 


\section{CONCLUSION}

This study examined the historical causes of farmer-herder conflicts in Kitui East Sub County in the period 1895-1963. Watering points and grazing pastures emerged as the main causes of conflict. Other causes included, incitement by politicians, cattle rustling and banditry, presence of SALW and ethnic animosity.

\section{RECOMMENDATIONS}

- Both the County government and national government should work together to see to it that drilling of more water points is done in all the villages of Mutitu sub County. These will avert frequent experienced conflicts during dry spells as a result of water competition for the livestock, irrigation and domestic use.

- There is need to address the proliferation of illicit weapons by strengthening the SALW agenda with intention to limit their flow and ownership among communities in Mutitu sub County of Kitui County.

- Strengthening the Anti- stock theft Unit in Mutitu sub County of Kitui County to curb cattle theft. In addition, more police stations with adequate personnel and insecurity deterrent facilities should be established.

- Political leaders should influence their communities positively since they determine and influence the escalation or de-escalation of violence or inter-ethnic conflicts.

- There is need to ensure adequate representation of marginalized groups in government arms like the civil service, cabinet and in the army. This will ensure that they are not sidelined in government, which is an important factor in policy making.

- Provision of quality infrastructure would generate employment through access to market by small scale holders and entrepreneurs. Roads should be constructed and communication network restored in the region making it accessible. This will lead to Improved physical infrastructure which in turn will lead to better increasing interaction between the warring communities, link them to the outside world, improve their access to information; mainstream them into the national economy and policy making process.

\section{REFERENCES}

[1] Elbadawi, I., and Sambanis, N, "Why are There So Many Civil Wars in Africa? Understanding and Preventing Violent Conflict," Journal of Africa Drought and Conflict in Kenya"s Dry lands. Environmental Management, Economics, 9, 3, October 2000: 244-269.

[2] Hussein, K. (1998). Conflict between Farmers and Herders in Semi-Arid Sahel and East Africa: Pastoral Land Tenure Series No.10. Overseas Development Group and Schools of Development Studies University Of East Anglia, U.K.

[3] Edossa, D. (2005). Indigenous Systems of Conflict Legislative Framework for Rural Water Management in Africa, 26-28 January 2005, Johannesburg.

[4] Wasonga, V. (2009). „The Linkages between Land-Use, Land Degradation and Poverty in Semi- Arid Kenya: The Case of Baringo Districtec. PhD Thesis, University Of Nairobi.

[5] Oba, G. (1992), Ecological Factors In Land Use Conflicts: Land Administration And Food Insecurity In Turkana, Kenya. Http://Www.Odi.Org.Uk/Work/Projects/Pdn/ Papers/33a.Pdf.

[6] Lenairoshi (2014) „Factors Influencing Conflict Resolution In Kenya: A Case of Baragoi Sub County Of Samburu County. "Master"s thesis, University Of Nairobi

[7] CICERO Report 2006:01 Vulnerability to Climate Stress - Local and Regional Perspectives Proceedings of Two Workshops January 27-28, 2005, World Agroforestry Centre, Gigiri, Nairobi and February 14, 2005, KEFRI Research Centre, Kitui

[8] Percival, V., \& Homer-Dixon, T.F (1998) Environmental Scarcitiy and Violent Conflicts: The Case of South Africa. Journal of Peace Research, 35 (3), (279-298)

[9] Galtung, J., „Cultural Violence (1990) 27.3 Journal of Peace Research 291-305.

[10] Kennedy. B. (2001). Population Reference Bureau. Environmental Scarcity and the Outbreak of Conflict. Washngton, DC

[11] Owuor, B., Mauta, W., \&Eriksen, S. (2011) „Sustainable Adaptation and Human Security: Interactions between Pastoral and Agro Pastoral Groups" in Dryland Kenya, Climate and Development, 42-58, Doi: 10.3763/Cdev.2010.0063 
[12] Eriksen, S. \& Lind, J., 2009. Adaptation as a Political Process: Adjusting to Drought and Conflict in Kenya ${ }^{e e}$ Drylands. Environmental Management, 43(5). 817-835. Doi: 10.1007/S00267-008-9189-0.

[13] Matheka, R. (1992) The Political Economy of Famine: Ecology and History in Machakos District During the Colonial Era. Master Thesis. Kenyatta University.

[14] Foeken, D., Owuor, S. \& Klaver, W. (2000). Leiden. African Study Centre. Crop Cultivation in Nakuru Town, Kenya: Practice and Potential.

[15] Lind, J., and Eriksen, S.(2006).The Impacts of Conflict on Household Coping Strategies: Evidence from Turkana and Kitui Districts in Kenya. DieErde, London: Routledge.

[16] Opiyo, F.E. O., Mureithi, S.M., \&Ngugi, R.K. (2011): The Influence of Water Availability on Pastoralist"es Resource Use in Kitui and Mwingi Districts of Kenya. Journal of Human Ecology.

[17] Ochieng, W. R (1985). A Modern History of Kenya. Nairobi: Macmillan Educational

[18] Were, G.S. \& Wilson, D.A. (1987). East Africa through a Thousand Years. Nairobi:

[19] Simiyu, V. (1974). "Land and Politics in Ukambani from the End of the 19th Century Up To 1933". Présence Africaine Editions. No. 89. pp. 101-146.

[20] Korir, M.K. (1991). History of Environmental Management in Kenya. Gaining Ground: Institutional Innovations in Land Use Management in Kenya, Kiririo, A and Juma, C. (Eds). Rev. Edition, Acts Press, African Centre for Technology Studies, Nairobi.

[21] Warurii, F (2008) Inter-Ethnic Conflicts: Trends, Causes, Effects and Interventions in Rumuruti Division of Laikipia County, Kenya (1963 - 2010) Master Thesis, Kenyatta University.

[22] Hornsby, C. (2012). Kenya: A History since Independence. London: I.B.Tauris \& Co Ltd.

[23] NSC. National conflict mapping and analysis. Peace and conflict trends in kenya. 2011.NSC Publication.

[24] Oyugi, W., Wanyande, P. \&Mbai, C. (2003). The Politics of Transition in Kenya: from KANU to NARK. Nairobi. Heinrich Boll Foundation Publishers.

[25] Ibrahim, D. \&Jenner, J. (1996). "Wajir Community Based Conflict Management”. USAID Conference on Conflict Resolution in the Great Horn of Africa, June 1996.

[26] Mkutu, K. A. (2008). Guns and Governance in the Rift Valley: Pastoralist Conflicts and Small Arms. Nairobi: East Africa Educational Publishers.

[27] Mohamud, A., and Ruto P, (2005). Conflict Management in Kenya: Towards Policy and Strategy Formulation, Practical Action, Nairobi.

[28] (Meredith M, 2011) States of Africa: A History of the Continent since Independence. Simon and Schuster. London

[29] Throup, D. \& Hornsby C. (1998). Multyparty Politics in Kenya, The Kenyatta And Moi States and the Triumph of the System in The 1992 Election. Oxford. James Curry. 1998.

[30] Adams, M., and Bradbury, M. (1995), Conflicts and Development: Organizational Development in Conflict Situation. Oxfam Discussion Paper N4. Oxfam UK and Ireland) Oxford.

[31] Wafula, D. 2018. Effects of Ethnic Conflicts on Livelihood of the Pokot/Turkana Communities in Kainuk and Sigor Divisions in Post-Colonial Kenya. Master Thesis, Kibabii University.

[32] Mwikali, W., (2018). Farmer-Herder Conflicts and Socio-Economic Development of the Local Communities in Mutitu Sub County of Kitui County, Kenya 1963-2013. Master Thesis. Kibabii University.

[33] Waweru, P. (2006). Continuity and Change in Samburu Pastoralism. under Colonial Rule, 1909-1963. Egerton University. LAP LAMBERT Academic Publishing.

[34] Lutz,G. \& Linder, W. (2004).Traditional Structures in Local Government. Berne. Institute of Political Science.

[35] Kratli,S \& Swift, J. (1999). Understanding and Managing Pastoral Conflict in Kenya. Uk. Institute of Development Studies. Pp. 31.

[36] GITAU, S. (2014) Conflicts between Pastoral Communities in East Africa. Case Study of the Pokot and Turkana. Masteres Thesis. University of Nairobi.

Citation: Winnifred Mwikali, et.al. "Historical Causes of Farmer-Herder Conflict in Kitui East Sub County, Kenya, 1895-1963". International Journal of Humanities Social Sciences and Education (IJHSSE), vol. 6, no.12, 2019, pp. 55-64. doi: http://dx. doi.org/10.20431/2349-0381.0612004.

Copyright: (C) 2019 Authors. This is an open-access article distributed under the terms of the Creative Commons Attribution License, which permits unrestricted use, distribution, and reproduction in any medium, provided the original author and source are credited. 